\section{The American Association for Thoracic Surgery}

\section{AATS Week Recap 2015}

AATS Week 2015 was a tremendous success, beginning with the 2015 AATS Mitral Conclave and concluding with the 95th AATS Annual Meeting. The Mitral Conclave took place in New York City on April 23-24 with a record attendance of over 1,100 registrants while the Annual Meeting, which took place from April 25-29 in Seattle, attracted over 2,750 cardiothoracic surgeons and other professionals specializing in the care of cardiothoracic patients.

The Week included a number of well-received innovative programmatic additions including an expert techniques video session at the Mitral Conclave and new Annual Meeting sessions on coronary bypass, optimal therapies for end-stage thoracic organ failure, and advanced imaging and paradigms for treatment of functional MR. The full Webcast of the Annual Meeting program is currently available on the AATS Web site (www.webcast.aats.org/2015).

Rounding out the educational experience was the exhibit area that featured resident, moderated, and allied health scientific posters as well as the JCTSE Top Gun and Jeopardy competitions; the AATS Learning Center; and Deep Dive Sessions in the CT Theatres, which provided attendees with a variety of unique interactive opportunities with industry colleagues.

Highlights of the meeting included:

- The Presidential Address, "Technological Innovation in Cardiothoracic Surgery: A Pragmatists Approach" by Dr Pedro del Nido

- The Basic Science Lecture by Dr Donald Inbger entitled "Biologically Inspired Engineering: The Next Technology Wave"

- The Honored Speaker Lecture, "Three Ideas About Changing Things" by Col. Casey Haskins

- A Saturday luncheon interview with Dr Lawrence H. Cohn

- Sunday "Legends Luncheons" including Drs Marc de Leval, Jean Deslauriers, and Tirone David

- The Lifetime Achievement Award being presented to Dr Timothy J. Gardner of Christiana Care Health System

- The Scientific Achievement Award being presented to Dr James L. Cox of Washington University

- The 18th Annual C. Walton Lillehei Resident Forum Award was presented to Dr Jeffery Cohen of Stanford University for his outstanding abstract submission, manuscript preparation, and presentation on "Creation of a Novel Endosymbiotic System for Photon Powered Myocardium in the Ischemic Heart"

To see more meeting highlights, view the AATS Daily News at http://www.thoracicsurgerynews.com/aats-annual-meeting. html, the one-stop source for all of the Seattle meeting coverage.

At its Annual Executive Session on April 28, Dr Joseph S. Coselli of Houston, TX, was inducted as the Association's 96th President. Additionally, the AATS Membership elected the following members to positions within the AATS Council.

- Dr Thoralf M. Sundt III of Boston, MA, PresidentElect;

- Dr Duke E. Cameron of Baltimore, MD, Vice President;

- Dr Marc R. Moon of St. Louis, MO, Secretary;

- Dr Shaf Keshavjee of Toronto, Canada, Treasurer; and

- Drs Jennifer S. Lawton of St. Louis, MO, and Friedrich W. Mohr of Leipzig, Germany, as Councilors, joining Drs David H. Adams, Pedro J. del Nido, J. William Gaynor, and David R. Jones to form the 2015-2016 AATS Council.

The membership endorsed the following actions based on the recommendations of the Council:

- Elected the following 54 surgeons to Active membership:

- Abbas E. Abbas, MD, Philadelphia, PA

- Pavan Atluri, MD, Philadelphia, PA

- Leora B. Balsam, MD, New York, NY

- David P. Bichell, MD, Nashville, TN

- Daniel J. Boffa, MD, New Haven, CT

- Munir Boodhwani, MD, Ottawa, ON, Canada

- Michael Bousamra, MD, Louisville, KY

- Brian Bruckner, MD, Houston, TX

- Enio Buffolo, MD, São Paulo, Brazil

- Massimo Caputo, MD, Bristol, United Kingdom

- Anna Maria Ciccone, MD, Rome, Italy

- David T. Cooke, MD, Sacramento, CA

- Marcelo Cypel, MD, Toronto, ON, Canada

- Francois Dagenais, MD, Quebec, QC, Canada

Antonio D'Andrilli, MD, Rome, Italy

Jonathan D'Cunha, MD, Pittsburgh, PA

- Laurent De Kerchove, MD, Brussels, Belgium

Chadrick E. Denlinger, MD, Charleston, SC

- Nimesh Desai, MD, Philadelphia, PA

Todd M. Dewey, MD, Dallas, TX

Torsten Doenst, MD, Jena, Germany

Alexander S. Farivar, MD, Seattle, WA

- Felix G. Fernandez, MD, Atlanta, GA

Lorenzo E. Ferri, MD, Montreal, QC, Canada

Kevin L. Greason, MD, Rochester, $M N$

Sean C. Grondin, MD, Calgary, AB, Canada

Kazuhiro Hashimoto, MD, Tokyo, Japan

- Viktor Hraska, MD, Sankt Augustin, Germany

James Huang, MD, New York, NY

- Douglas R. Johnston, MD, Cleveland, $\mathrm{OH}$

- Robert J.M. Klautz, MD, Leiden, The Netherlands

- Theodoros Kofidis, MD, Singapore, Singapore

- Martin Kostolny, MD, London, United Kingdom

- Alexander Kulik, MD, Boca Raton, FL 
Leonard Y. Lee, MD, New Brunswick, NJ

Moishe Liberman, MD, Montreal, QC, Canada

Jules Lin, MD, Ann Arbor, MI

Hari R. Mallidi, MD, Houston, TX

Simon Maltais, MD, Nashville, TN

Silvana F. Marasco, Melbourne, Victoria, Australia

Xu Meng, MD, Beijng, China

Kagami Miyaji, MD, Sagamihara, Japan

Gaetano Paone, MD, Detroit, MI

Patrick Perier, MD, Bad Neustadt, Germany

Ourania Preventza, MD, Houston, TX

Varun Puri, MD, St. Louis, MO

Basel Ramlawi, MD, Houston, TX

Fraser Rubens, MD, Ottawa, ON, Canada

Isabelle Schmitt-Opitz, MD, Zurich, Switzerland

- Sunil Singhal, MD, Philadelphia, PA

Edward G. Soltesz, MD, Cleveland, $\mathrm{OH}$

John M. Stulak, MD, Rochester, $M N$

Akihiko Usui, MD, Nagoya, Japan

Zhe Zheng, MD, Beijing, China

- Dissolved the International Advisory Committee and redistributed its responsibilities to the various Committees

- Created an AATS Workshop with the NHLBI

- Supported the SAGR Committee in creating a thoracicfocused clinical trial

- Supported an AATS Focus Course in China to be held in Shanghai in March of 2016

- Continued joint educational activities EACTS, ESTS, STS, AmSECT, APACVS, ASCVTS, World Congress of Pediatric \& Cardiology and Cardiac Surgery, Duke University, All Children's Hospital, and FACTS-Care

Please make plans to attend AATS Week 2016, beginning with the Aortic Symposium in New York City on May 12-13 followed by the 96th Annual Meeting of The American Association for Thoracic Surgery in Baltimore, MD, on May 14-18.

\section{Awards From the 95th AATS Annual Meeting}

The Association is excited to announce the winners of the 2015 AATS Allied Health, Moderated, and Resident Poster Competitions, all of which were held during the 95th AATS Annual Meeting in Seattle, Washington.

\section{AATS Allied Health Poster Competition}

"An Interdisciplinary Education Initiative to Promote Blood Conservation in Cardiac Surgery"

Tamara Goda, DNP, ANP-BC, East Carolina Heart Institute at Vidant Medical Center

\section{AATS Moderated Poster Competition Adult Cardiac \\ "David vs Goliath: Valve-Sparing Root Replacement Im- proves Outcomes Compared to Bentall Procedures in Pa- tients With Aortic Root Dilatation" \\ Dr Maral Ouzounian, University of Toronto}

\author{
Congenital \\ "Durable Ventricular Assist Device Support for End-Stage \\ Heart Failure: An Extended Role in Pediatric and Congen- \\ ital Population" \\ Dr Ed Peng, Freeman Hospital
}

\section{General Thoracic}

"Should Lobectomy Be Performed wWhen Unsuspected pN2 Disease Is Found at the Time of Planned Lung Cancer Resection? A National Cancer Data Base Analysis"

Dr Chi-Fu Jeffrey Yang, Duke University

\section{AATS Resident Poster Competition Adult Cardiac}

1st Place: "Long-Term Outcome of Isolated Coronary Artery Bypass Grafting in Patients With Left Ventricular Dysfunction"

Dr Yangsin Lee, Mitsui Memorial Hospital

2nd Place: "Pulmonary Embolectomy for Acute and Subacute Type a Pulmonary Embolism on Cardiopulmonary Bypass With a Beating Heart"

Dr Scott Johnson, Medical University of South Carolina

3rd Place: "Effect of Aortic Valve Morphology on Haemodynamics and Aneurysm Formation in the Thoracic Aorta" Dr Pouya Youssefi, St. George's Hospital

\section{Congenital}

1st Place: "Is the Rastelli Procedure Falsely Maligned?" Dr Mohammed Al-Jughiman, University of Toronto

2nd Place: "Cardiac Function After Tetralogy of Fallot/ Complete Atrioventricular Canal Repair"

Dr Elizabeth Stephens, Columbia University

3rd Place: "Translocation of the Descending Thoracic Aorta for Relief of Distal Tracheal and Proximal Bronchial Compression"

Dr Mark Roeser, Texas Children's Hospital

\section{General Thoracic}

1st Place: "Treatment Effect of Rapamycin in Laryngotracheal Stenosis"

Dr Gary Schwartz, Johns Hopkins Hospital

2nd Place: "Stereotactic Radio Surgery in the Octogenarian"

Dr Nicholas Baker, University of Pittsburgh Medical Center

3rd Place: "CT-Guided Microcoil VATS Resection of Lung Nodules"

Dr Laura Donahoe, St. Joseph's Health Centre 